Matthew J. Suriano

\title{
The Politics of Dead Kings
}

\section{Dynastic Ancestors in the Book of Kings and Ancient Israel}

[Die Politik der Toten Könige. Dynastische Vorfahren im Buch der Könige und im Antiken Israel.]

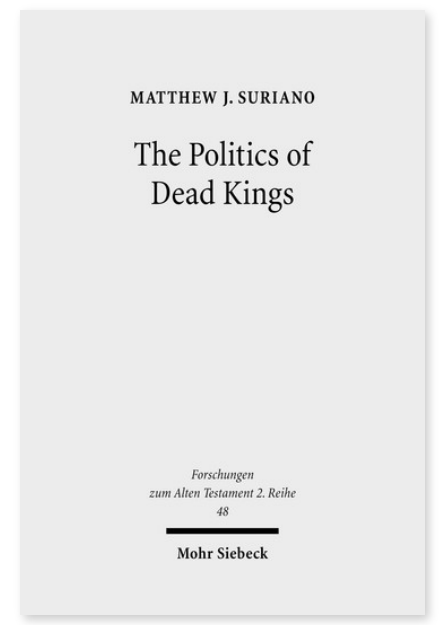

2010. XVI, 211 Seiten. FAT II 48

ISBN 978-3-16-151146-2

DOI 10.1628/978-3-16-151146-2

eBook PDF $69,00 €$

ISBN 978-3-16-150473-0

fadengeheftete Broschur $69,00 €$
Veröffentlicht auf Englisch.

In der Erzählung von Israel und Juda im Buch der Könige wird das Ende einer königlichen Herrschaft in einer Reihe von Standardaussagen zusammengefaßt, die mit dem poetischen Ausdruck für Tod beginnen: »Und der König] legte sich zu seinen Vätern«. Die Schlußäußerungen drehen sich alle um das Problem des königlichen Todes und der Nachfolge, eingebettet in einen kurzen Epilog, der normalerweise aus einer Begräbnisnotiz (in den königlichen Gräbern) und der Vorstellung des Nachfolgers bestand. Als solche übermittelten die formelhaften Erklärungen königliche Legitimität durch die Ideale politischer Kontinuität und die geradlinige Übertragung der Macht. Die politische Ideologie in den Epilogen des Buches der Könige stimmt mit der politischen Landschaft der Levante während der Eisenzeit überein. Die formelhaften Epiloge der Könige spiegelten die Bedeutung der Beerdigungsrituale und der königlichen Gräber wider, denn damit konnten sie dem politischen Problem begegnen, das durch den Tod eines Königs und den anschließenden Akt dynastischer Nachfolge gestellt wurde.

Matthew J. Suriano BA in History from University of Illinois, Urbana-Champaign; MA in Ancient History from Jerusalem University College, MA and PhD in Hebrew Bible and Northwest Semitics from University of California, Los Angeles; has taught at University of Southern California's School of Religion and was a Lecturer in Near Eastern Languages and Cultures at UCLA with a visiting faculty appointment in the Department of Religious Studies at the University of California, Santa Barbara; currently Visiting Lecturer in Hebrew Bible and Ancient Judaism in the Department of Religious Studies at Indiana University, Bloomington.
Jetzt bestellen:

https://mohrsiebeck.com/buch/the-politics-of-dead-kings-9783161511462?no_cache=1

order@mohrsiebeck.com

Telefon: +49 (0)7071-923-17

Telefax: $+49(0) 7071-51104$ 